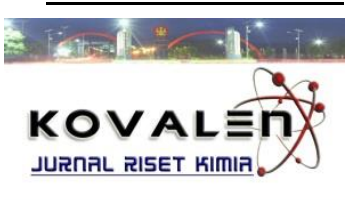

\title{
UJI AKTIVITAS ANTIOKSIDAN EKSRTRAK LUMUT HATI (Marchantia polymorpha)
}

[Antioxidant Activity Assay of Liverworts (Marchantia polymorpha) Extract]

\author{
Nurhaeni ${ }^{1}$, Gladys ${ }^{1^{\star}}$, Jaya Hardi ${ }^{1}$ \\ 1) Jurusan Kimia, Fakultas MIPA, Universitas Tadulako, Palu \\ J. Soekarno Hatta Km.9, Kampus Bumi Tadulako Tondo Palu, Telp. 0451- 422611 \\ *)Coresponding author: gladyspatoki@gmail.com
}

Diterima 6 Desember 2019, Disetujui 29 Desember 2019

\begin{abstract}
The research is about antioxidant activity of the liverworts (Marchatia polymorpha) extract based on the level of a polar solvent. This research was done by maceration of liverworts by using $n$-hexane, ethyl acetate and ethanol solvent. The n-hexane, ethyl acetate, and ethanol fraction were tested the antioxidant activity by using DPPH method. The result was obtained for antioxidant activity $\left(\mathrm{IC}_{50}\right)$ on $\mathrm{n}$ hexane extract, ethyl acetate, ethanol and vitamin C is $1065.33 \mathrm{ppm}, 1326.52 \mathrm{ppm}, 1876.11 \mathrm{ppm}$, and $13.45 \mathrm{ppm}$, respectively. The liverworts extract was identified contains secondary metabolites compounds of flavonoid, tannins, polyphenol, alkaloid, and steroid.
\end{abstract}

Keywords: Liverwort extract, antioxidant, $I C_{50}$

\begin{abstract}
ABSTRAK
Telah dilakukan penelitian tentang aktivitas antioksidan ekstrak lumut hati (Marchantia polymorpha) berdasarkan tingkat kepolaran pelarut. Penelitian ini diawali dengan ekstraksi lumut hati secara maserasi bertingkat menggunakan 3 macam pelarut meliputi $n$-heksan, etil asetat dan etanol. Ekstrak n-heksan, etil asetat dan etanol diuji aktivitas antioksidannya dengan metode DPPH. Hasil yang diperoleh untuk aktivitas antioksidan $\left(\mathrm{IC}_{50}\right)$ pada ekstrak $n$-heksan, etil asetat, etanol dan vitamin C masing - masing 1065,33 ppm, 1326,52 ppm, 1876,11ppm, 13,45 ppm. Pada ekstrak lumut hati teridentifikasi senyawa metabolit sekunder golongan flavonoid, tanin dan polifenol, alkaloid dan steroid.
\end{abstract}

Kata Kunci : Lumut hati, antioksidan, $I C_{50}$. 


\section{LATAR BELAKANG}

Lumut merupakan tumbuhan tingkat rendah yang dapat beradaptasi dilingkungan basah dan kering, seperti Indonesia dan dapat (Saputra, 2013). Tumbuhan epifit ini yang banyak ditemukan tumbuh di batang pohon, kayu mati, kayu lapuk, tanah, atau batuan, dengan penyinaran yang cukup (Windadri, 2009).

Lumut berpotensi dimanfaatkan sebagai bahan obat-obatan karena dilaporkan mengandung senyawa aktif metabolit sekunder. Krisnayana et al. (2010), melaporkan bahwa lumut mengandung senyawa aktif metabolit sekunder yang dapat digunakan sebagai senyawa antibakteri, antifungi, antitumor dan antikanker. Pengujian aktifitas antibakteri pada lumut Oktoblepharum albidium dapat menghambat bakteri S.epidermis dan P.aeruginosa. Penghambatan yang terjadi terhadap bakteri dipengaruhi oleh adanya kandungan senyawa metabolit sekunder (Wiwid et al., 2014). Kemampuan antibakteri pada lumut ditentukan oleh keberadaan senyawa bioaktif yang ada di dalamnya seperti alkaloid, flavonoid, polifenol, saponin dan terpenoid (Fadhillah, 2010). Berdasarkan penelitian senyawa tersebut, lumut juga berpotensi sebagai antioksidan. Antioksidan merupakan senyawa pemberi elektron pada senyawa yang memiliki elektron yang tidak berpasangan (radikal bebas). Antioksidan dapat meredam atau mengurangi dampak negatif radikal bebas dengan cara mengikatnya lalu mengubahnya menjadi tidak berbahaya bagi tubuh.

\section{METODE PENELITIAN}

\section{Bahan dan Peralatan}

Bahan dasar yang digunakan pada penelitian ini adalah lumut hati Marchantia polymorpha yang diperoleh dari kabupaten sigi, kecamatan kulawi, desa bulutono. Bahan-bahan lain yang diperlukan yaitu metanol teknis, $n$-heksan teknis, etil asetat teknis, etanol teknis, akuades, aluminum foil, kertas saring, vitamin C, DPPH (1,1difenil-2-pikrilhidrazil), serbuk $\mathrm{Mg}, \mathrm{HCl}$ pekat (Merck), $\mathrm{FeCl}_{3}$ (Merck), kloroform (Merck), anhidrida asam asetat (Merck) dan $\mathrm{H}_{2} \mathrm{SO}_{4}$ pekat (Merck).

Peralatan yang digunakan yaitu : neraca analitik, blender, pipet mikro, corong buchner, corong pisah, kuvet, spektrofotometer UV-Vis (Perkinelmer) seperangkat alat rotary vakum evaporator.

\section{Prosedur Penelitian}

\section{Preparasi Sampel}

Sampel lumut hati dalam keadaan segar, dibersihkan menggunakan air bersih, kemudian dikeringkan pada suhu ruang sampai kering, dan selnjutnya dihaluskan menggunakan blender serta diayak menggunakan ayakan 60 mesh.

Tahap eksraksi lumut hati dengan metode maserasi (Lisnawati, 2014)

Eksraksi dilakukan menggunakan metode maserai secara bertinggkat dengan menggunakan tiga jenis pelarut. Eksraksi pertama digunakan pelarut $\mathrm{n}$ - 
Heksan dengan cara menimbang tepung lumut hati sebanyak $100 \mathrm{~g}$, kemudian dimasukan kedalam elenmeyer $1000 \mathrm{ml}$ lalu ditambahkan 1000 ml n-heksan campuran disimpan selama 48 jam sambil sesekali diaduk, kemudian disaring dengan penyaring vakum. Filtrat yang diperoleh pelarutnya dipisahkan dengan rotary vakum evaporator sehingga didaptkan eksrak kental lumut hati. Residu yang diperoleh dikeringkan, dan selanjutnya dimasukan dalam elenmeyer untuk dieksrak kembali dengan pelarut etil asetat dan kemudian pelarut etanol dengan perlakuan yang sama pada eksrak menggunakan n-heksan

\section{Uji Golongan Senyawa Secara Kualitatif} (Harborne, 1987).

\section{Uji Flavonoid}

Sebanyak $1 \mathrm{ml}$ sampel ditambahkan 0,5 gram serbuk magnesium dan 10 tetes $\mathrm{HCl}$ pekat (pereaksi shinoda), bila bereaksi positif akan menghasilkan larutan berwarna jingga, merah muda atau merah.

\section{Uji Polifenol dan Tanin}

$1 \mathrm{ml}$ sampel ditambahkan 10 tetes larutan $\mathrm{FeCl}_{3} 1 \%$ bila bereaksi positif akan menghasilkan warna hijau, merah, ungu, biru atau hitam yang kuat.

\section{Uji Alkaloid}

Sebanyak $1 \mathrm{ml}$ sampel ditambahkan 2-3 tetes pereaksi Dragendorf, bila bereaksi positif akan menghasilkan endapan merah jingga.

\section{Uji Steroid/Triterpenoid}

Sebanyak $1 \mathrm{ml}$ sampel ditambahkan 2-3 tetes kloroform lalu ditambahkan anhidrida asam asetat dan 5 tetes asam sulfat pekat, bila bereaksi positif akan menghasilkan larutan berwarna biru atau hijau.

\section{Pengujian Aktivitas Antioksidan dengan Menggunakan Metode DPPH (Zuhra et al., 2008).}

Ekstrak n-heksan, etil asetat dan etanol masing - masing ditimbang sebanyak $25 \mathrm{mg}$ dan dimasukkan kedalam labu ukur $25 \mathrm{~mL}$ kemudian dilarutkan dengan metanol dan dicukupkan volumenya sehingga diperoleh konsentrasi 1000 ppm. Kemudian dilakukan pengenceran dengan menambahkan metanol sehingga diperoleh sampel dengan konsentrasi $(10,30,50,70$, dan 90 ppm). Untuk penentuan aktivitas antioksidan masing-masing konsentrasi dipipet sebanyak $0,2 \mathrm{ml}$ larutan sampel dengan pipet mikro dan dimasukan ke dalam tabung reaksi, kemudian ditambahkan 3,8 ml larutan DPPH $50 \mu \mathrm{M}$. Campuran dihomogenkan dan dibiarkan selama 30 menit ditempat gelap, serapan diukur dengan spektrofotometer UV-Vis pada panjang gelombang $517 \mathrm{~nm}$. Aktivitas antioksidan sampel ditentukan oleh besarnya hambatan serapan radikal DPPH melalui perhitungan persentase inhibisi serapan DPPH dengan menggunakan rumus :

$\%$ Inhibisi $=\frac{\text { Absorbansi Kontrol-Absorbansi Sampel }}{\text { Absorbansi Kontrol }} \times 100$

Keterangan:

Abs. Kontrol = Absorban DPPH $50 \mu \mathrm{M}$

Abs. Sampel = Absorbansi Sampel Uji 
Nilai $I_{50}$ masing-masing konsentrasi sampel dihitung dengan menggunakan rumus persamaan regresi linier. $I_{50}$ adalah bilangan yang menunjukkan konsentrasi ekstrak yang mampu menghambat aktivitas suatu radikal sebesar 50\% Untuk menentukan $\mathrm{IC}_{50}$, diperlukan persamaan kurva standar dari $\%$ inhibisi sebagai sumbu y dan konsentrasi fraksi antioksidan sebagai sumbu $\mathrm{x} . \quad \mathrm{IC}_{50}$ dihitung dengan cara memasukkan nilai $50 \%$ ke dalam persamaan kurva standar sebagai sumbu y kemudian dihitung nilai $\mathrm{x}$ sebagai konsentrasi $\mathrm{IC}_{50}$.

\section{HASIL DAN PEMBAHASAN}

\section{Hasil Uji Fitokimia Ekstrak Lumut Hati}

Hasil uji fitokimia menunjukkan ekstrak polar dan lumut hati memiliki kandungan flavonoid dan tannin serta polifenol (Tabel 1). Kandungan flavonoid dan polifenol diasumsikan mampu menghasilkan aktvitas antioksidan.

\begin{tabular}{|c|c|c|c|c|}
\hline \multirow[b]{2}{*}{ No } & \multirow{2}{*}{$\begin{array}{l}\text { Golongan } \\
\text { Senyawa }\end{array}$} & \multicolumn{3}{|c|}{ Ekstrak } \\
\hline & & $\begin{array}{c}n- \\
\text { Heksan }\end{array}$ & $\begin{array}{c}\text { Etil } \\
\text { Asetat }\end{array}$ & Etanol \\
\hline 1 & Flavonoid & - & - & $\begin{array}{c}+ \\
\text { jingga }\end{array}$ \\
\hline 2 & $\begin{array}{l}\text { Tanin \& } \\
\text { Polifenol }\end{array}$ & - & $\begin{array}{c}+ \\
\text { merah }\end{array}$ & $\stackrel{+}{\text { merah }}$ \\
\hline 3 & Alkaloid & $\begin{array}{c}+ \\
\text { Endapan } \\
\text { merah } \\
\text { jingga }\end{array}$ & $\begin{array}{c}+ \\
\text { Endapan } \\
\text { merah } \\
\text { jingga }\end{array}$ & $\begin{array}{c}+ \\
\text { Endapa } \\
\text { n merah } \\
\text { jingga }\end{array}$ \\
\hline 4 & Steroid & $\begin{array}{c}+ \\
\text { Hijau } \\
\text { pekat }\end{array}$ & $\begin{array}{c}+ \\
\text { Hijau } \\
\text { pekat }\end{array}$ & $\begin{array}{c}+ \\
\text { Hijau } \\
\text { pekat }\end{array}$ \\
\hline
\end{tabular}

Keterangan : (+) : Teridentifikasi

$(-)$ : Tidak teridentifikasi
Aktivitas Antioksidan Ekstrak Lumut Hati

Pengujian aktivitas antioksidan dilakukan dengan penentuan \% inhibisi ekstrak $n$-heksan, etil asetat dan etanol pada masing-masing konsentrasi yaitu 10 ppm ; 30 ppm ; 50 ppm ; 70 ppm dan 90 ppm. Nilai inhibisi tertinggi masing masing untuk pelarut $n$-heksan, etil asetat dan etanol yaitu 6,26 \%; 8,23\% ; dan 13,92\% (Gambar 1).

Perbandingan dari ketiga jenis pelarut yang digunakan dalam proses ekstraksi mempengaruhi aktivitas antioksidan yang diperoleh. Hasil ekstraksi menggunakan tiga jenis pelarut yang memiliki tingkat kepolaran yang berbedabeda, akan menghasilkan rendemen eksrak yang berbeda pula (Nurjanah et al., 2012). Soeksmanto et al. (2007), menyatakan bahwa penggunaan pelarut yang berbeda tingkat kepolaran mempengaruhi jenis senyawa yang terekstrak.

Hasil yang diperoleh diketahui bahwa pada penggunaan pelarut etanol menunjukkan nilai $I_{50}$ paling kecil, yaitu 1065,33 ppm atau dengan kata lain memiliki aktivitas antikoksidan yang lebih tinggi dibandingkan fraksi etil asetat (1326,52 ppm) dan n-heksan (1876,11 ppm). Hal ini terjadi karena di dalam eksrak etanol lumut hati mengandung senyawa flavonoid dan polifenol yang bersifat polar yang memiliki kemampuan menangkal radikal bebas karna memiliki gugus $(-\mathrm{OH})$. 


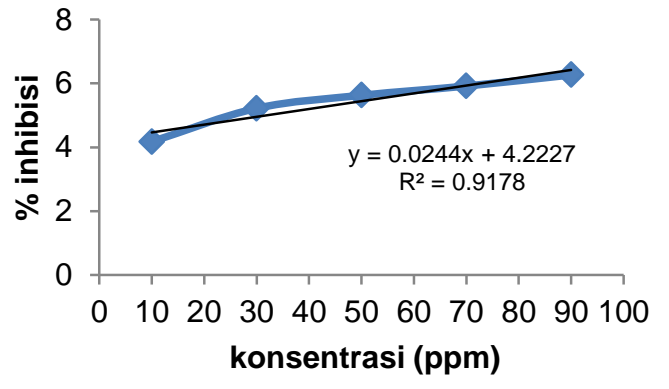

(a)

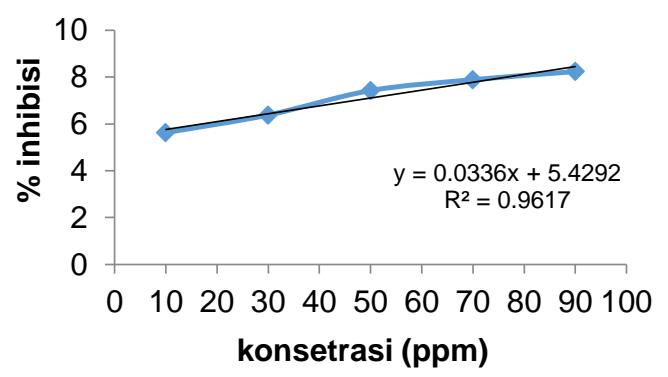

(b)

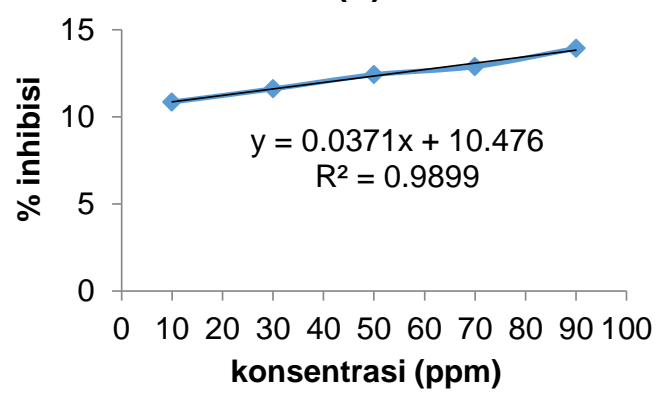

(c)

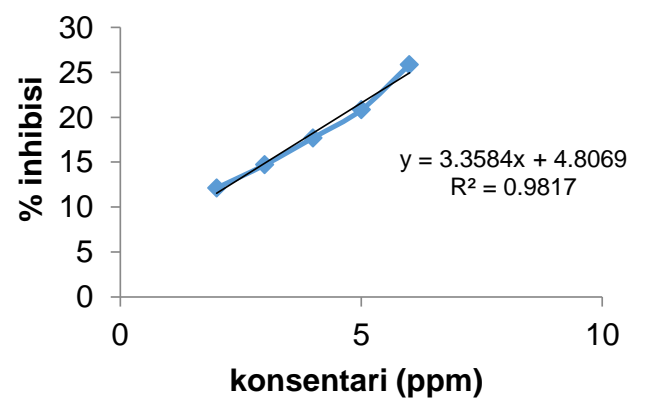

(d)

Gambar 1 Kurva Hubungan Konsentrasi ekstrak n-heksan (a), etil asetat (b), etanol (c), dan Vitamin C (d) Terhadap Persentase Inhibisi.

Asakawa, 2007 dalam Fadhilla, 2012 melaporkan sebagian besar lumut marchantia kaya akan senyawa fenolik dan terpenoid terutama jenis mono, sesqui, dan diterpenoid, senyawa-senyawa lipofilik aromatis (bibenzil, bisbibenzil, benzoad, sinamat, alkil fenol rantai panjang, naftalen, isokumarin) dan asetogenin umumnya senyawa-senyawa tersebut larut dalam pelarut organic yang bersifat polar.

Jika dibandingkan nilai $I_{50}$ pada pembanding asam askorbat dengan nilai $I_{50}$ ekstrak etanol yang diperoleh, dapat diketahui bahwa nilai $\mathrm{IC}_{50}$ asam askorbat 13,45 ppm. Hal ini menandakan bahwa sifat antioksidan senyawa bioaktif yang terkandung dalam eksrak lumut hati bersifat sangat lemah jika dibandingkan dengan asam askorbat.

Menurut penelitian Nurjanaj et al. (2012) mengenai aktivitas antioksidan dan komponen bioaktif semanggi Air (marsilea crenata) dengan menggunakan pelarut klorofom, etil asetat dan metanol nilai $\mathrm{IC}_{50}$ masing - masing ekstrak sebesar 1285,39 ppm; 915,03 ppm dan 634,73 ppm. Sedangkan menurut penelitian yang dilakukan oleh Tristanto et al. (2014) tentang optimalisasi pemanfaatan daun lamun (thalassia hemprichii) Sebagai sumber antioksidan alami pada pelarut $n$ heksan dan etil asetat nilai $\mathrm{IC}_{50}$ masingmasing ekstrak sebesar 139,50 ppm; 25,98 ppm. Dan menurut penelitian Azkiyah (2013) tentang isolasi senyawa aktif antioksidan dari Fraksi n-heksana tumbuhan paku memiliki nilai $I_{50} 38,701$ ppm. Hasil penelitian tersebut lebih baik dibandingkan uji aktivitas antioksidan antioksidan ekstrak lumut hati (Marchantia polymorpha). 
Blois (1985) dalam Molyneux (2004) menyatakan bahwa aktivitas antioksidan dapat dibagi menjadi beberapa kategori yaitu sangat kuat, kuat, sedang, lemah dan sangat lemah. Antioksidan dikatakan sangat kuat apabila memiliki nilai $I_{50}$ kurang dari 50 ppm, antioksidan kuat memiliki nilai $\mathrm{IC}_{50}$ berada pada kisaran 50 ppm hingga 100 ppm, antioksidan sedang memiliki nilai $\mathrm{IC}_{50}$ berkisar antara 100 ppm hingga 150 ppm, antioksidan lemah memiliki kisaran 150 ppm hingga 200 ppm dan antioksidan dikatakan sangat lemah apabila memiliki nilai $I_{50}$ lebih dari 200 ppm.

\section{KESIMPULAN}

Senyawa metabolit sekunder yang teridentifikasi dalam ekstrak kasar lumut hati yakni flavonoid, alkaloid, tanin dan polifenol, steroid. Nilai $I_{50}$ eksrak etanol, etil asetat dan $\mathrm{n}$-heksan lumut hati masingmasing diperoleh 1065,33 ppm, 1326,52 ppm, 1876,11ppm. Ketiga ekstrak ini tergolong antioksidan sangat lemah. Jadi, dapat dikatakan bahwa ekstrak lumut hati tidak berpotensi sebagai antioksidan. Dari pengujian fitokimia eksrak lumut hati diketahui dari ketiga ekstrak bersifat polar, semi polar, dan nonpolar.

\section{DAFTAR PUSTAKA}

Azkiyah. 2013. Isolasi senyawa aktif antioksidan dari fraksi n-heksan tumbuhan paku. Skripsi. Jakarta: Fakultas kedokteran dan ilmu kesehatan. UIN.
Fadhilla, R. 2010. Aktivitas Antimikroba Ekstrak Metanol Lumut Hati (Marchantia paleacea) Terhadap Bakteri Patogen Dan Pembusuk Makanan. Tesis. Bogor: Institut Pertanian Bogor.

Harborne J.B. 1987. Metode Fitokimia: Penuntun Cara Modern Menganalisis tumbuhan. Ed. II. Diterjemahkan oleh Padmawinata K, Sudiro I. Bandung: Institut Teknologi Bandung. 1978.hlm. 3-15.

Krisnayana, MP, Putra, IP, Putra dan Rahayu, AT. 2010. Potensi Lumut Sebagai Zat Antimikroba, Bogor: Institut Pertanian Bogor.

Lisnawati, 2014. Aktivitas Antioksidan Ekstrak Daun Kelor (Moringa olefera L.) dari Berbagaitingkat Kepolaran Pelarut. Skripsi. Palu: FMIPA Kimia. Universitas Tadulako.

Molyneux, P. 2004. The Use Of The Stable Free Radical Diphenylpicrylhydrazyl (DPPH) for Estimating Antioxidant Activity. Songklanakarin J. Sci. Technol., 26(2): 211-219.

Nurjanah., Azka, A., Abdullah, A. 2012. Aktivitas antioksidan dan komponen bioaktif semanggi air (Marsilea renata). Asian Journal of Innovation and Entrepreuneurship,1(3) .

Saputra, A. 2013. Identifikasi Lichen di Kebun Raya Bukit Sari Kabupaten Tebo Provinsi Jambi. Skripsi. Jambi: FKIP Universitas Negeri Jambi.

Soeksmanto, A. Hapsari, Y. dan Simanjuntak, P. 2007. Kandungan Antioksidan pada Beberapa Bagian Tanaman Mahkota Dewa, Phaleria macrocarpa (Scheff) Boerl. (Thymelaceae). Biodiversita, 8(2): 92-95

Tristanto, R., Putri, M A., A.D, Situmorang, A P., Suryanti. 2014. Optimasi 
pemanfaatan daun lamun Thalasia

Hemprichii sebagai sumber

antioksidan alami. Jurnal Saintek

Perikanan, 10(1) : 26-29.

Widyana, W., Khotimah, S.,Lovadi, I. 2014.

Aktivitas Antibakteri Ekstrak Lumut

Octoblepharum albidium Hedw

terhadap Pertumbuhan

Staphylococcus epidermidis dan

Pseudomonas aeruginosa.

Protobiont, 3(2): 166-170.

Windadri, F.I. 2009. Keanekaragaman

Lumut Pada Marga Pandanus Di

Taman Nasional Ujung Kulon,

Banten. Jurnal Natur Indonesia.

11(2): 89-93

Zuhra, C.F, Tarigan, JBT., Sihotang, H. 2008. Aktivitas antioksidan senyawa flavonoid dari daun katuk (souropus androgunus (L) merr). Jurnal Biologi Sumatra, 3(1): 7-10. 